\title{
Source Apportionment of Coarse and Fine Particulate Matter at Navi Mumbai, India
}

\author{
P. Kothai ${ }^{1}$, I.V. Saradhi ${ }^{1}$, P. Prathibha ${ }^{1}$, Philip K. Hopke ${ }^{2}$, \\ G.G. Pandit ${ }^{*}$, V.D. Puranik ${ }^{1}$ \\ ${ }^{1}$ Environmental Assessment Division, Bhabha Atomic Research Centre, Trombay, Mumbai - 400085. \\ ${ }^{2}$ Centre for Air Resources Engineering and Science, Clarkson University, Potsdam, \\ NY 13699- 5808, USA
}

\begin{abstract}
Atmospheric particulate matter in two size fractions $2.5-10 \mu \mathrm{m}$ and $\leq 2.5 \mu \mathrm{m}$ were collected on nuclepore polycarbonate filter papers and were analyzed for elements using NAA and EDXRF. Varimax rotated factor analysis identified five major sources contributing to coarse and fine particulate mass. FA-MLR technique is applied to apportion the sources. Source apportionment studies showed maximum contribution of the coarse fraction was from sea salt $(35 \%)$ and crustal (25\%) sources. A considerable amount of the mass was also contributed from industrial (14\%), vehicular (10\%) and fugitive emissions (7\%). These results also showed the percentage contribution of soil, two-stroke emission with fugitive dust, industrial emission, motor vehicles and sea salt to the average fine mass concentration was $3 \%, 18 \%, 23 \%, 29 \%$ and $9 \%$, respectively. The contribution of each source to their constituent elements also has been determined using the same technique.
\end{abstract}

Keywords: Factor Analysis (FA); Multiple Linear Regression (MLR); Sources; Receptor model; Coarse; Fine.

\section{INTRODUCTION}

Deterioration of air quality is a major problem faced by millions of urban Indians. Most Indian cities are highly polluted with airborne particulate matter and have concentrations that are well above the

\footnotetext{
"Corresponding author. Fax: + 91-022-25505313

E-mail address: ggp@barc.gov.in
}

recommended limits of WHO and US EPA (Sadasivan and Negi, 1990; Gupta and Kumar, 2006). Particulate matters (PM) are small solid or liquid particles suspended in ambient air. The term PM10 refers to fine particles or droplets that are 10 microns or less in aerodynamic diameter ( $\mathrm{Xu}$ et al, 2008). Historically, the association between $\mathrm{PM}_{10}$ and mortality has been manifested in many air pollution episodes and it has been shown by 
many epidemiological studies (Pope et al., 1995). High concentrations of $\mathrm{PM}_{2.5}$ and $\mathrm{PM}_{10}$ particles (that is particles with aerodynamic diameters of 2.5 and $10 \mu \mathrm{m}$ and less) in the atmosphere have been shown to have significant impacts on human health in major urban areas around the world (Dockery, 1993) and several reports revealed significant correlations between particulate matter levels and increased respiratory and cardiovascular diseases, and mortality (Pope et al., 2002; Almeida et al., 2005). Particles are introduced into the atmosphere from a variety of anthropogenic activities and natural sources (Miranda and Thomaz, 2008).

Vehicular emission, industrial emission as well as combustion of fuel for domestic heating and cooking purposes are considered as primary anthropogenic sources for the urban air pollution. In spite of the abovementioned common problems, main cities are nowadays facing unique environmental issues such as management of municipal solid waste, bio-medical solid waste and hazardous waste produced by high urbanization and heavy industrialization. In India major sources of urban air pollution include coal combustion, oil refineries and industrial manufacturing facilities (Murray et al., 2001). However, automobile exhaust, emission from smallscale workshop and soil derived aerosols are considered as other important contributing sources (Dubey and Pervez, 2008). Therefore, it is essential to delineate the contributing airborne particulate sources in view of environmental quality management and human health perspectives. Also the application of effective abatement strategies to reduce PM levels is only possible when the emission sources have been uniquely identified and characterized (Viana et al., 2006).

There are several types of multivariate receptor models used in the source apportionment studies (Henry et al., 1984). Factor Analysis (FA) and Principal Component Analysis (PCA) are commonly used receptor techniques, that can lead to the identification of the sources and they cannot directly provide the quantitative estimation of the sources. However as mentioned by Okamoto et al. (1990), receptor models can also be used in the estimation of the contributing concentration for each emission source by simple manipulation of the solutions. One such approach is Absolute Principal Component Analysis (APCA) (Thurston and Spengler, 1985). Using this technique, scores for each sample can be obtained and following this by regressing the mass concentrations of the samples with Absolute Principal Component Score (APCS), mass contribution of each identified source can be estimated. The present study is mainly focused on the inventory and apportionment of potential sources of $\mathrm{PM}_{2.5}$ (Fine) and $\mathrm{PM}_{2.5-10}$ (Coarse) to know the impact and contribution of rapid industrialization and vehicular growth on a residential area situated in Vashi in Navi Mumbai region in the vicinity of Mumbai, India. Coarse and fine particulate matter has been collected in the study area using a Gent sampler and the elemental data obtained after the Instrumental Neutron Activation Analysis 
(INAA) and Energy Dispersive X-Ray Fluorescence (EDXRF) analysis. These data have been utilized for Principal Component Analysis (PCA) studies to identify their probable sources. Finally, the mass contribution of each source and each element in the respective source has been apportioned using PCA with Multiple Linear Regression (PCA-MLR).

\section{MATERIALS AND METHODS}

\section{Sampling}

The Gent stacked filter unit sampler (Hopke et al., 1997) has been used for the collection of fine $(<2.5 \mu \mathrm{m})$ and coarse $(2.5$ $10 \mu \mathrm{m})$ particles on Nuclepore polycarbonate filters of $8 \mu \mathrm{m}$ and $0.4 \mu \mathrm{m}$ pore size, respectively. Samples were collected at an average flow rate of $16 \mathrm{lpm}$ for a sampling period of 24 hours. The sampler has been placed at a height of $15 \mathrm{~m}$ above the ground on the terrace of a building in Vashi that is situated in Navi Mumbai. Navi Mumbai is the largest planned new city near Mumbai and is situated at $73^{\circ}$ East longitude and $20^{\circ}$ North latitude. The city is very near to Thane Belapur area that was known as largest industrial belt in India. The industrial estate is mainly comprised of chemical, bulk drugs and intermediates, dye and dye intermediates, pharmaceutical, pesticide, petrochemical, engineering good and textile manufacturing industries. A national highway passes $2 \mathrm{Km}$ from the sampling site.

\section{$P M$ mass and BC measurement}

Nuclepore polycarbonate filters were preweighed and post weighed to determine the gravimetric mass of the coarse and fine particulate mass using a Mettler balance with the readability of $10 \mu \mathrm{g}$. A ${ }^{210}$ Po charge eliminator was used to neutralize the charge accumulated on the surface of the filters before weighing. Black Carbon (BC) concentration in the fine filters was measured using EEL Smoke Stain Reflectometer (Model 43D) by reflectance method (Biswas et al., 2003, Begum et al., 2004). Reflectometer has been calibrated using preselected clean control filter taken from the same batch and the calibration was repeated after the analysis of few filter samples as mentioned by Vallius et al. (2005).

\section{Sample analysis}

Multielemental analysis of filter samples was performed by EDXRF and INAA. The samples were first analysed for $\mathrm{Si}, \mathrm{S}, \mathrm{Ca}, \mathrm{Ti}$ and $\mathrm{Pb}$ using EDXRF (Negi et al., 2002) followed by the analysis of $\mathrm{Zn}, \mathrm{Fe}, \mathrm{Co}, \mathrm{Na}, \mathrm{K}$, $\mathrm{Sb}, \mathrm{Cr}$, and $\mathrm{Sc}$ using neutron activation analysis. Suitable thin film standards were used for the calibration of EDXRF system. In case of NAA, elemental concentrations were obtained by following the comparative method of analysis that is by the co irradiation of the samples and the standards together.

\section{Statistical Analysis: Factor Analysis - Multi} Linear Regression model

Over the last two decades, multivariate analysis has been widely used to identify 
sources of ambient particles. In this study to identify and estimate the possible sources of coarse and fine size particles, PCA was applied (Srivastava et al., 2008). The main objective of PCA is to reduce a large number of variables to a smaller set of factors that retain most of the information in the original data set (Hopke, 1985; Marcazzan et al., 2003) and this property of multivariate PCA method has also been explained by Karar et al. (2007). In PCA, a set of multiple correlated variables is replaced by a small number of independent variables by orthogonal transformations (Salvador et al., 2003). This transformation is achieved by diagnolizing the correlation matrix of the variables through the computation of eigenvalues and eigenvectors. Each factor explains the maximum total variance of the data set and this set is completely uncorrelated with the rest of the data. The factor loadings obtained after the varimax rotation gives the correlation between the variables and the factor. Thus, the chemical elements with higher loading in each factor are interpreted as fingerprints of emission source that it represents. Software like SPSS ${ }^{\mathrm{TM}}$ and Statgraphics can be utilized to perform multivariate factor analysis (Tripathi et al., 2003).

The FA model used in this study is expressed as a bilinear model.

$$
C_{i t}=\sum L_{i j} \times S_{j t}+E_{i t}
$$

Where $C_{i t}$ is the standardized value of concentration of $i$ th species for $t$ th sample, $\mathrm{S}_{\mathrm{jt}}$ is the factor score of the $j$ th common factor for $t$ th sample, $\mathrm{L}_{\mathrm{ij}}$ is the factor loading of the $i$ th species of the $j$ th source and $E_{i t}$ is the residual of $i$ th species in the $t$ th sample not accounted by the $\mathrm{j}$ sources or factors (Negi et al., 1998, Kumar et al., 2001). The 'absolute zero' PC score (APCS) has been evaluated by adding an extra sample wherein all the elemental concentrations are zero. Because the PCA results are based on standardized data, the true zero for each factor score should be calculated as

$$
\left(Z_{0}\right)_{j}=\frac{0-\bar{C}_{j}}{\sigma_{j}}=-\frac{\bar{C}_{j}}{\sigma_{j}} .
$$

The rescaled scores are known as APCS. Finally regression can be used to derive the source contributions, expressed as

$$
M_{i}=\zeta_{0}+\sum_{k=1}^{p} \zeta_{k} A P C S_{k i}
$$

Where $\mathrm{M}_{\mathrm{i}}$ is the measured concentration in sample i. In general, $M_{i}$ could be the total mass concentrations of the chemical species or the total mass concentrations measured directly, such as by gravimetric filter weighing. $\mathrm{APCS}_{\mathrm{ki}}$ is the rotated absolute component score for source $\mathrm{k}$ in sample $\mathrm{i}$. $\zeta_{\mathrm{k}} \mathrm{APCS}_{\mathrm{ki}}$ is the mass contribution in sample $i$ made by source $\mathrm{k}$. $\zeta_{0}$ is the mass contribution made by sources unaccounted for in the PCA (Song et al., 2006). Regressing daily fine and coarse mass data on these APCS estimated the contribution from each source to the ambient 
particulate mass collected. The detailed computation and the advantages of APCS have been presented by Thurston et al (1985).

\section{RESULTS AND DISCUSSION}

\section{Concentration levels of particulate matter}

The daily average mass concentrations of coarse $\left(\mathrm{PM}_{2.5-10}\right)$ and fine $\left(\mathrm{PM}_{2.5}\right)$ particulate matter collected at Vashi site and their statistical summary are presented in Table1. The 24-hour average mass concentration of coarse particulate is in the range of $17-235$ $\left(\mu \mathrm{g} / \mathrm{m}^{3}\right)$ with a median value of $105\left(\mu \mathrm{g} / \mathrm{m}^{3}\right)$ and in fine particulates, concentration ranges from $7.7\left(\mu \mathrm{g} / \mathrm{m}^{3}\right)-115.8\left(\mu \mathrm{g} / \mathrm{m}^{3}\right)$ with a median value of $35.5\left(\mu \mathrm{g} / \mathrm{m}^{3}\right)$. The monthly variations of coarse and fine particulate mass have been presented using Box-Whisker plots in Figs. 1 2 respectively. In the Box-Whisker plot, the box represents the distribution of 25-75 percentile values and the symbol $\square$ represents the mean value. The values beyond 75

Table 1. Statistical summary of the coarse and fine particulate matter mass concentration at Vashi site during the study period.

\begin{tabular}{ccc}
\hline Parameter & Coarse particle $\left(\mathrm{PM}_{2.5-10}\right)$ & Fine particle $\left(\mathrm{PM}_{2.5}\right)$ \\
\hline Mean $\left(\mu \mathrm{g} / \mathrm{m}^{3}\right)$ & 107.85 & 44.03 \\
Median $\left(\mu \mathrm{g} / \mathrm{m}^{3}\right)$ & 105.03 & 35.45 \\
Standard deviation $\left(\mu \mathrm{g} / \mathrm{m}^{3}\right)$ & 48.52 & 26.01 \\
Maximum $\left(\mu \mathrm{g} / \mathrm{m}^{3}\right)$ & 235 & 115.83 \\
Minimum $\left(\mu \mathrm{g} / \mathrm{m}^{3}\right)$ & 16.67 & 7.69 \\
Number of filters exposed & 82 & 82 \\
\hline
\end{tabular}

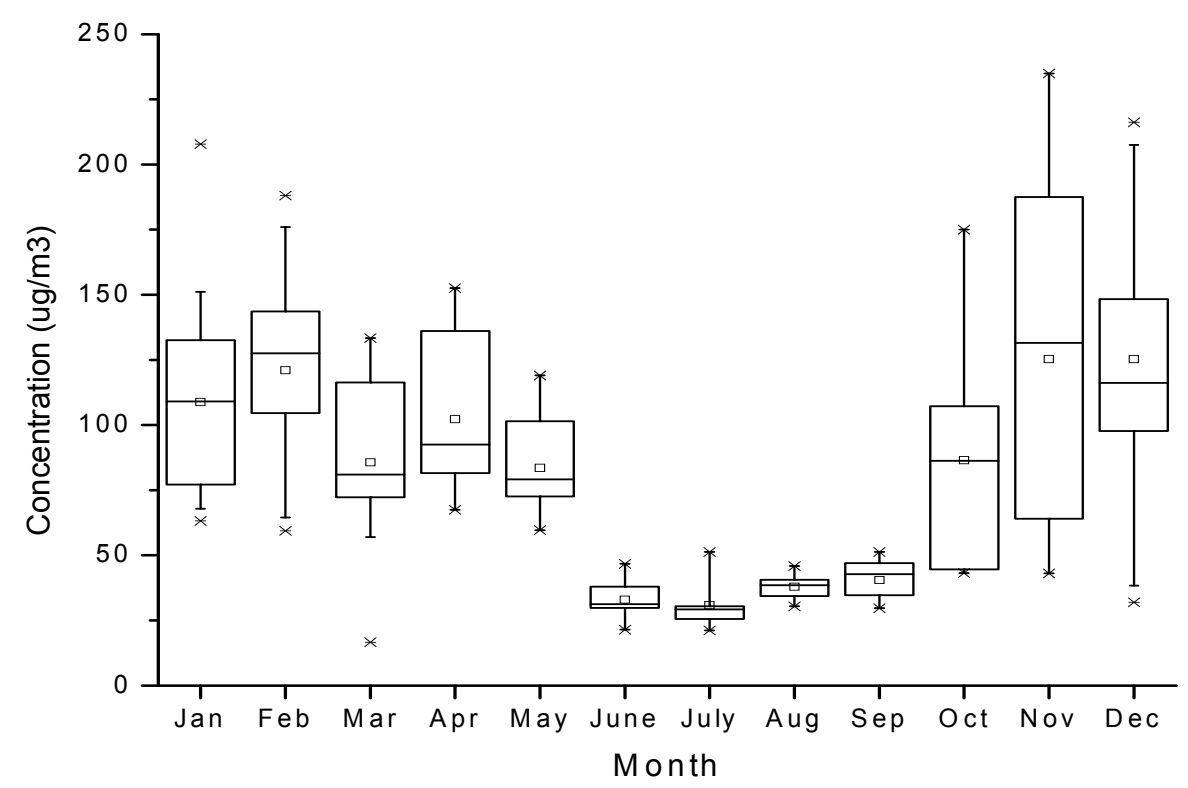

Fig. 1. Box-Whisker plot for monthly coarse mass concentration at Vashi site during the study period. 
Table 2. The mean and standard deviations of elemental concentrations of coarse and fine particulate matter at Vashi site.

\begin{tabular}{ccccc}
\hline \multirow{2}{*}{ Parameter } & \multicolumn{2}{c}{ Coarse particulate matter } & \multicolumn{2}{c}{ Fine particulate matter } \\
& Mean $\left(\mathrm{ng} / \mathrm{m}^{3}\right)$ & S.D.* $\left(\mathrm{ng} / \mathrm{m}^{3}\right)$ & Mean $\left(\mathrm{ng} / \mathrm{m}^{3}\right)$ & S.D.* $\left(\mathrm{ng} / \mathrm{m}^{3}\right)$ \\
\hline Mass & 48529.19 & 44031.85 & 26011.26 & 10785.80 \\
$\mathrm{BC}$ & - & - & 8000.70 & 4000.94 \\
$\mathrm{Zn}$ & 743.47 & 389.08 & 331.88 & 140.34 \\
$\mathrm{Fe}$ & 2848.17 & 314.27 & 624.48 & 290.19 \\
$\mathrm{Co}$ & 24.46 & 13.77 & 4.5 & 2.2 \\
$\mathrm{Na}$ & 730.77 & 150.58 & 462.5 & 105.7 \\
$\mathrm{~K}$ & 997.43 & 461.01 & 561.37 & 81.53 \\
$\mathrm{Sb}$ & 26.65 & 17.05 & 25.84 & 23.40 \\
$\mathrm{Cr}$ & 34.43 & 13.42 & 17.67 & 6.29 \\
$\mathrm{~S}$ & 2623.9 & 656.77 & 2133.95 & 868.01 \\
$\mathrm{Si}$ & 5169.47 & 826.27 & 1095.4 & 627.17 \\
$\mathrm{Ca}$ & 2513.83 & 497.16 & 580.56 & 35.87 \\
$\mathrm{Ti}$ & 249.78 & 85.17 & 76.12 & 26.14 \\
$\mathrm{Sc}$ & 14.52 & 11.17 & 6.8 & 0.61 \\
$\mathrm{Ni}$ & 5.03 & 1.11 & 8.04 & 5.41 \\
$\mathrm{~Pb}$ & 133.68 & 105.52 & 123.40 & 44.16 \\
\hline
\end{tabular}

*S.D. - Standard Deviation

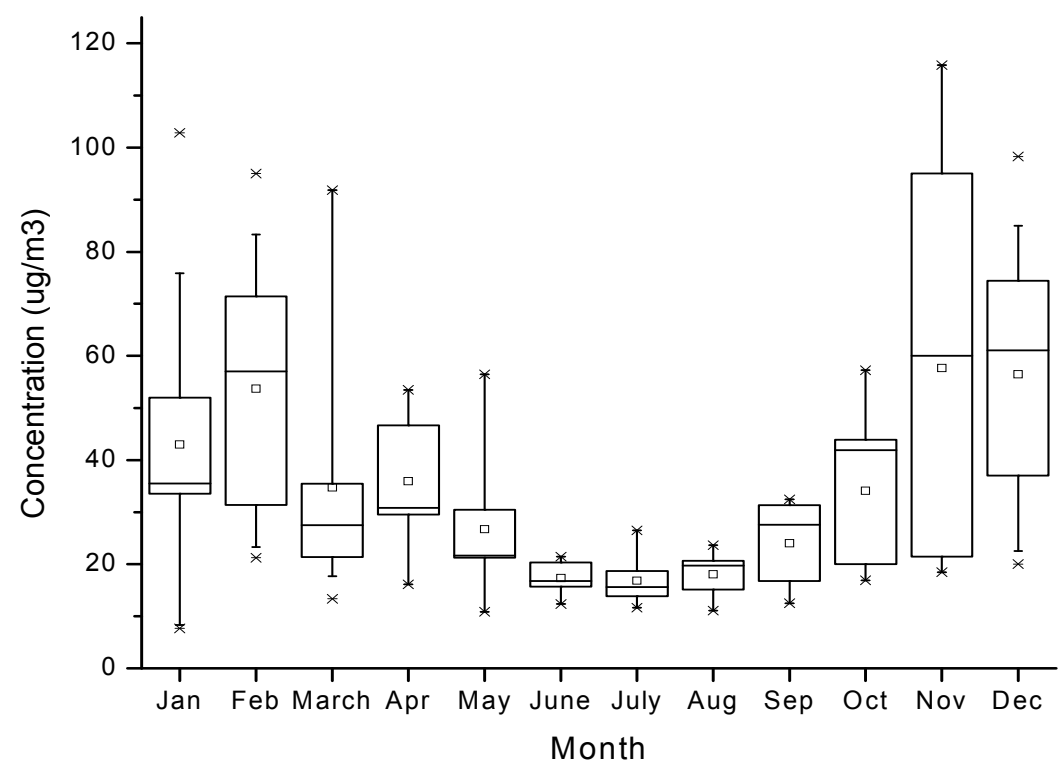

Fig. 2. Box-Whisker plot for monthly fine mass concentration at Vashi site during the study period.

percentile and 25 percentile are given as percentile and 25 percentile are given as whiskers. The plots (Figs. 1-2) of both coarse and fine concentrations show higher mass depositions during the winter season (November to February) that could be due to 
temperature inversion. Due to lower temperatures during November, December, January and February the mixing height becomes lower and the particulate concentration becomes high with wide variation in the concentration range. This is clearly seen in the box whisker plots from the length of the whiskers and from the $75^{\text {th }}$ and $25^{\text {th }}$ percentile values. Also the plots indicate comparatively lower concentration of particulate matter during March, April and May, which could be attributed to very high mixing heights. The lowest values are observed during monsoon period (June, July, August and September) due to street cleaning and dust control by heavy precipitation in Mumbai. Similar trends has been observed by Gupta and Kumar (2006).

\section{Source identification using Principal}

\section{Component Analysis}

The results of elemental concentrations obtained in $\mathrm{PM}_{2.5-10}$ and $\mathrm{PM}_{2.5}$ and their standard deviation are presented in Table 2. The mean values presented in Table 2 are obtained from a data set of 84 samples. Fourteen elements were determined for all the samples in coarse and fine fraction. Average concentrations of various elements range from few $\mathrm{ng} / \mathrm{m}^{3}$ to thousands of $\mathrm{ng} / \mathrm{m}^{3}$. Multivariate factor analysis was adopted to help identification of dominant source categories (Wang et al., 2008) and the results obtained by varimax rotated factor analysis for coarse and fine particles are presented in Tables 3-4, respectively. The first factor of PCA results of $\mathrm{PM}_{2.5-10}$ (Table 3) showed higher loadings for $\mathrm{Fe}, \mathrm{Sc}$, Ti, Si and $\mathrm{Ca}$ with the maximum percentage of variance $(41.89 \%)$. This pattern of elements indicates their origin from soil as it contains typical elements of crustal origin. Factor 2 explained $21.78 \%$ of the variance with high loadings of $\mathrm{Pb}, \mathrm{Co}$ and $\mathrm{Sb}$. The main source of the $\mathrm{Pb}$ in this factor could be resuspension of roadside dust or fugitive emission from the industries situated in the nearby industrial belt. As leaded gasoline was banned in India in 2000 (Singh and Singh, 2006), it is suspected that road dust may contain comparatively higher concentration of accumulated $\mathrm{Pb}$ due to its past emissions over the years.

The third factor with high loadings of $\mathrm{Cr}$ and $\mathrm{Ni}$ can be attributed to a hazardous waste disposal site located at about $5 \mathrm{Km}$ from the sampling site or it can also be contributed from industries. Since the industrial belt comprises of engineering goods and dye industries which could be considered as the main contributor of this factor. This source is contributing about $15.08 \%$ variance to the total variance. Factor 4 containing high values for $\mathrm{Zn}$ and $\mathrm{S}$ with the variance of $8.37 \%$ can be labeled as vehicular emission. Because $\mathrm{Zn}$ is considered as an indicator element for twostroke vehicles as it is used as an additive in the lubricating oil (Chueinta et al., 2000). Such a zinc factor is commonly seen in regions where there is substantial use of twostroke engines (Begum et al., 2004). Factor 5 explained $5.07 \%$ of the variance with high values of $\mathrm{Na}$ and $\mathrm{K}$ indicates sea spray as the source. 
Table 3. Principal Component Analysis (PCA) with varimax rotation for all $\mathrm{PM}_{2.5-10}$ data from vashi site.

\begin{tabular}{ccccccc}
\hline Element & Soil & Fugitive dust & Industry & $\begin{array}{c}\text { Vehicular } \\
\text { emission }\end{array}$ & Sea salt & Communality \\
\hline $\mathrm{Zn}$ & 0.3731 & 0.2284 & -0.2672 & 0.8523 & -0.0821 & 0.9960 \\
$\mathrm{Fe}$ & 0.9717 & 0.0685 & -0.0056 & 0.1138 & -0.0653 & 0.9663 \\
$\mathrm{Co}$ & 0.2159 & 0.8670 & 0.1004 & 0.0745 & -0.0215 & 0.8145 \\
$\mathrm{Na}$ & -0.0845 & -0.2980 & -0.0284 & -0.1374 & 0.8755 & 0.8822 \\
$\mathrm{~K}$ & -0.0058 & -0.0085 & 0.4379 & 0.0150 & 0.8058 & 0.8416 \\
$\mathrm{Sb}$ & -0.0457 & 0.9737 & -0.0471 & 0.0872 & -0.1398 & 0.9797 \\
$\mathrm{Cr}$ & -0.0649 & -0.0209 & 0.9621 & -0.1920 & 0.1418 & 0.9873 \\
$\mathrm{~S}$ & 0.3720 & 0.2298 & -0.2678 & 0.8521 & -0.0842 & 0.9962 \\
$\mathrm{Si}$ & 0.9241 & 0.0757 & -0.0862 & 0.2083 & 0.0517 & 0.9133 \\
$\mathrm{Ca}$ & 0.9647 & 0.0086 & -0.0525 & 0.1723 & -0.0330 & 0.9644 \\
$\mathrm{Ti}$ & 0.9617 & -0.0099 & -0.01836 & 0.1727 & -0.0342 & 0.9564 \\
$\mathrm{Sc}$ & 0.9714 & 0.0681 & -0.0085 & 0.1145 & -0.0628 & 0.9655 \\
$\mathrm{Ni}$ & -0.0302 & -0.0452 & 0.9646 & -0.1916 & 0.1119 & 0.9827 \\
$\mathrm{~Pb}$ & -0.0311 & 0.8884 & -0.1529 & 0.2216 & -0.1631 & 0.8894 \\
$\% \mathrm{Var}$ & 41.89 & 21.78 & 15.08 & 8.37 & 5.07 & Total=92.19 \\
Eigen value & 5.93 & 3.11 & 2.11 & 1.1 & 0.7 & \\
\hline
\end{tabular}

Table 4. Principal Component Analysis (PCA) with varimax rotation for all $\mathrm{PM}_{2.5}$ data from vashi site.

\begin{tabular}{ccccccc}
\hline Element & Soil & $\begin{array}{c}\text { Two stroke vehicle \& } \\
\text { fugitive dust }\end{array}$ & Industry & $\begin{array}{c}\text { Motor } \\
\text { vehicle }\end{array}$ & Sea salt & Communality \\
\hline $\mathrm{BC}$ & 0.10079 & 0.2316 & -0.1447 & 0.7985 & 0.1481 & 0.8604 \\
$\mathrm{Fe}$ & 0.9490 & 0.08421 & -0.2311 & 0.1419 & -0.06522 & 0.9856 \\
$\mathrm{Zn}$ & 0.1781 & 0.9192 & -0.1366 & -0.0889 & -0.0487 & 0.9058 \\
$\mathrm{Sc}$ & 0.5442 & 0.7434 & -0.2159 & -0.1487 & -0.1217 & 0.9324 \\
$\mathrm{Co}$ & 0.0938 & 0.9116 & -0.094 & 0.1921 & 0.0527 & 0.8812 \\
$\mathrm{Na}$ & -0.1877 & -0.0201 & 0.0640 & 0.1356 & 0.8571 & 0.7928 \\
$\mathrm{~K}$ & 0.0188 & -0.0167 & -0.0234 & 0.0439 & 0.9093 & 0.8300 \\
$\mathrm{Sb}$ & -0.0390 & 0.9282 & -0.2001 & 0.1414 & -0.0049 & 0.9232 \\
$\mathrm{Cr}$ & -0.2406 & -0.1491 & 0.9433 & -0.1460 & 0.0121 & 0.9915 \\
$\mathrm{Ti}$ & 0.9624 & 0.1401 & -0.1849 & 0.0910 & -0.0288 & 0.9892 \\
$\mathrm{Si}$ & 0.9593 & 0.1180 & -0.1933 & 0.1441 & -0.0347 & 0.9936 \\
$\mathrm{Ni}$ & -0.2180 & -0.1712 & 0.9412 & -0.0591 & 0.0232 & 0.9668 \\
$\mathrm{~Pb}$ & -0.2397 & -0.1502 & 0.9429 & -0.1519 & 0.0171 & 0.9926 \\
$\mathrm{~S}$ & 0.2804 & 0.4879 & -0.1396 & 0.8695 & 0.0477 & 0.8784 \\
$\mathrm{Ca}$ & 0.9468 & 0.1096 & -0.1850 & 0.1636 & -0.1118 & 0.9820 \\
$\%$ var & 43.57 & 16.20 & 13.4 & 11.17 & 8.37 & Total=92.71\% \\
$\mathrm{Eigen}$ & 6.48 & 2.45 & 2.05 & 1.74 & 1.11 & \\
\hline
\end{tabular}

PCA of fine particulate matter identified five factors with the total variance of $92.71 \%$.
Factor 1 explained $43.57 \%$ of variance with high loadings of elements such as $\mathrm{Si}, \mathrm{Ca}, \mathrm{Ti}$, 


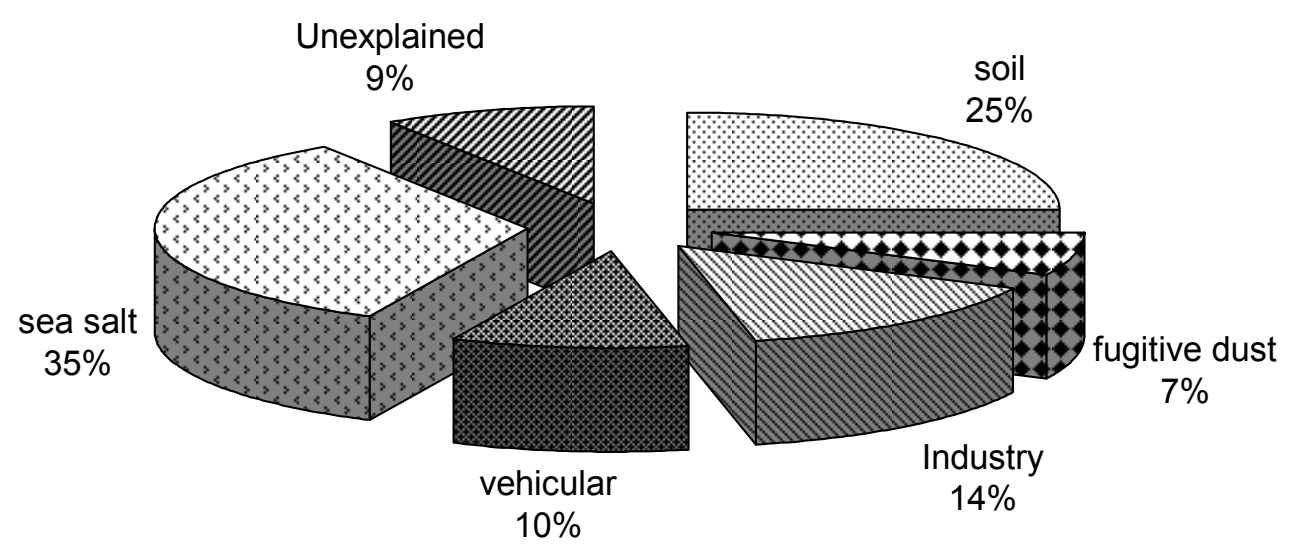

Fig. 3. Source apportionment of coarse particulate matter in the study area.

Sc and Fe. These finger print elements of soil clearly indicate the crustal source contribution to the factor. Factor 2 explained about $16.2 \%$ of the variance and in this factor $\mathrm{Zn}$ is associated with other elements such as Sc, Co and $\mathrm{Sb}$. This can be identified as the emission from two-stroke engine exhaust along with resuspended dust. Apparently the fugitive dust and the two-stroke engine emissions were not resolved in the fine fraction. Third factor with $\mathrm{Cr}$, $\mathrm{Ni}$ and $\mathrm{Pb}$ explaining $13.4 \%$ of the variance can be labeled as hazardous waste disposal site where the industrial wastes of Mumbai are being disposed or it could be industrial emission. It is difficult to ensure the exact sources without having the specific emission details of the industries in the surrounding area. However, the present data combined with meteorological data can be used to identify the local sources accurately. Factor 4 with high loadings of $\mathrm{BC}$ and $\mathrm{S}$ can be identified as motor vehicle emission and this factor explained a variance of $11.17 \%$. The highway at about $2 \mathrm{~km}$ from the site with heavy traffic could be the main source for the major contributing elements in this factor. The last factor with $\mathrm{Na}$ and $\mathrm{K}$ together clearly indicates its origin from sea salt.

\section{Source Apportionment using Principal Component Analysis - Multilinear Regression}

The Absolute Factor Scores were then obtained following the procedure of Thurston et al. (1984) and were regressed against the mass concentrations of coarse and fine particulate matter to apportion the percentage mass contribution of each identified source. The same procedure has been applied in apportioning the individual elemental contribution to each source. The source apportionments of coarse and fine particulate matter are presented in Figs. 3-4.

Coarse particulate matter collected over the sampling period in Vashi showed a maximum contribution of $35 \%$ from sea salt. The crustal source contributed $25 \%$, while the contribution from industry or the solid waste disposal site was found to be $14 \%$. Vehicular and fugitive emissions contributed $10 \%$ and 


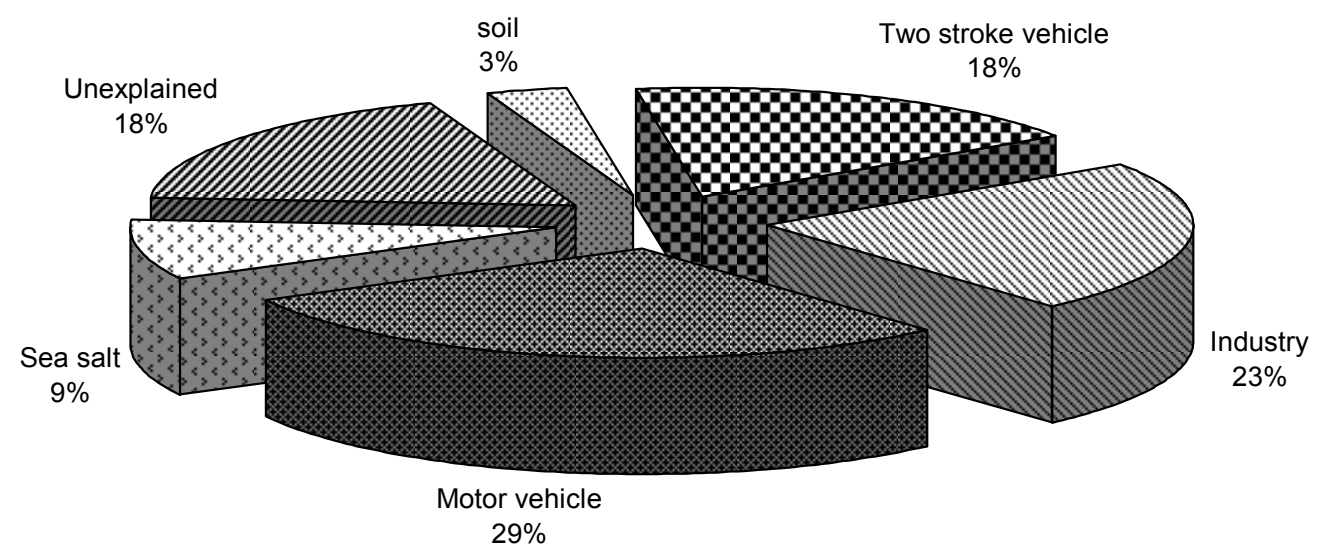

Fig. 4. Source apportionment of fine particulate matter in the study area.

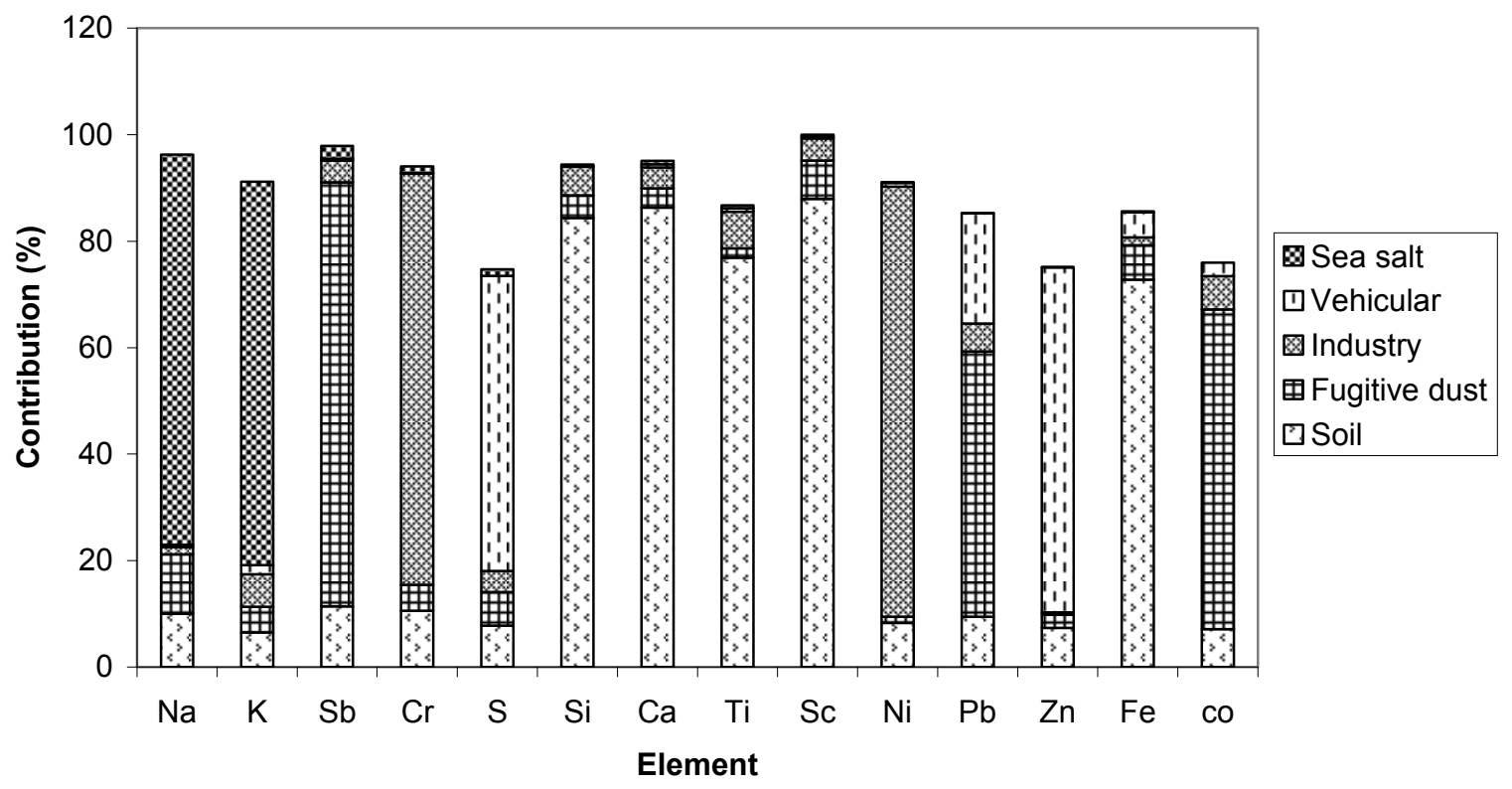

Fig. 5. Source apportionment of elements (in \%) in coarse particulate matter.

$7 \%$, respectively. In the case of fine particulate matter, the maximum mass has been contributed by vehicular sources. Particularly two-stroke vehicular emission has contributed $18 \%$ and motor vehicle contributed $29 \%$.

For fine mass, $23 \%$ of the mass has been contributed by industry and $9 \%$ from sea salt. Crustal sources contributed to only $3 \%$ in the fine fraction. Characterization of secondary compounds may help in explaining the remaining $18 \%$ of the fine mass concentration. Studies on source identification of aerosols in Mumbai conducted by Sadasivan et al. (1984) showed crustal and sea salt as the major contributing sources of the region. In the case of a study conducted at two traffic junctions in Mumbai by Kumar et al. (2001) road dust as well as vehicular emission was found to be 


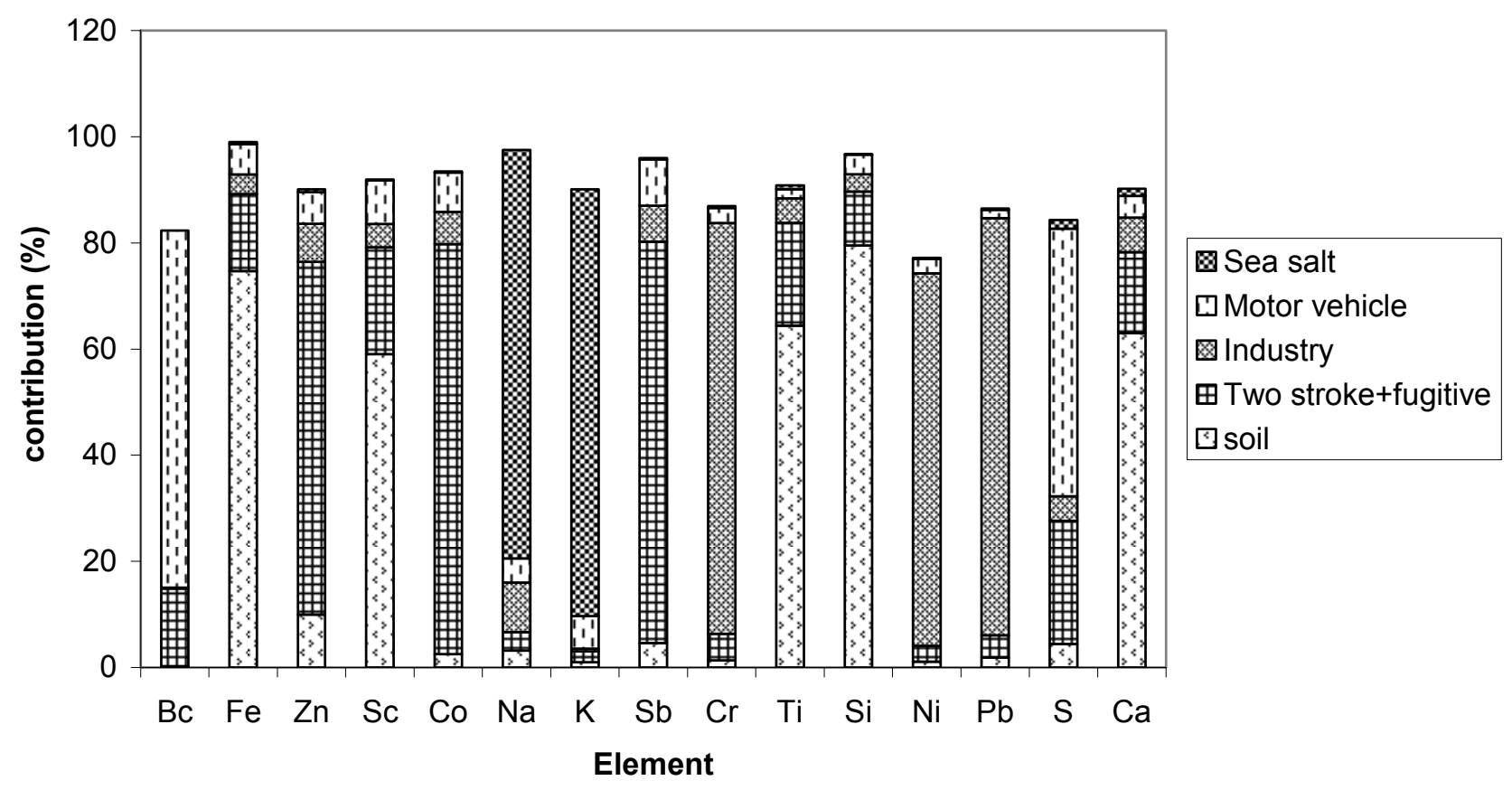

Fig. 6. Source apportionment of elements (in \%) in fine particulate matter

contributing more than marine, coal combustion and industrial emissions.

The percent contributions of elements in each source for both the size fractions are presented in Figs. 5-6. The contributions to most of the elements to the coarse and fine mass concentration from different sources have been found to be above $75 \%$. Improved elemental characterization of the particulate matter for more trace elements and secondary compounds such as sulphate and nitrate may help in explaining the remaining mass contributed from currently unobserved sources.

\section{CONCLUSIONS}

Airborne particulate matter in two size fractions $\mathrm{PM}_{2.5-10 \mu \mathrm{m}}$ and $\mathrm{PM}_{2.5 \mu \mathrm{m}}$, collected at a residential site in Vashi have been analysed for chemical composition using INAA and EDXRF. Using principal component analysis, possible emission sources were identified. Sources observed in both the size fractions are very much similar except vehicular emission in the fine fraction, where it has been resolved in to two factors. Following the factor identification, regression of unscaled factor scores with the mass concentrations of coarse and fine particulate matter apportioned the mass percentage of each contributing source. The same technique has been utilized for the apportionment of mass contribution of each element to the observed sources.

\section{ACKNOWLEDGMENTS}

The authors sincerely thank the International Atomic Energy Agency, Vienna 
for supporting this project (RAS/7/013). The authors also wish to thank H.S. Kushwaha, Director, Health, Safety and Environment Group, BARC for his constant support and encouragement.

\section{REFERENCES}

Almeida, S.M., Pio, C.A., Freitas, M.C., Reis, M.A. and Transcoso, M.A. (2005). Source Apportionment of Fine and Coarse Particulate Matter in a Sub-Urban area at the Western European Coast. Atmos. Environ. 39: 3127-3138.

Bilkis, A.B., Kim, E., Biswas, S.K. and Hopke, P.K. (2004). Investigation of Sources of Atmospheric Aerosols at Urban and SemiUrban Areas in Bangladesh. Atmos. Environ. 38: 3025-3038.

Biswas, S.K., Tarafdar, S.A., Islam, A., Khaliquzzaman, M., Tervahattu, $H$. and Kupiainen, K. (2003). Impact of Unleaded Gasoline Introduction on the Concentration of Lead in the Air of Dhaka, Bangladesh. $J$. Air and Waste Manage. Assoc. 53: 13551362.

Dockery D. W. (1993). Fine Particle Pollution and Health Effects. New England. $J$. Medical. 329: 1753.

Dubey, N. and Pervez, S. (2008). Investigation of Variation in Ambient $\mathrm{PM}_{10}$ levels within an Urban-Industrial Environment. Aerosol Air Qual. Res. 8: 54- 64.

Gupta, I. and Kumar, R. (2006). Trends of Particulate Matter in Four Cities in India. Atmos. Environ. 40: 2552-2566.
Henry, R.C., Lewis C.H., Hopke, P.K. and Williamson H.J. (1984). Review of Receptor Model Fundamentals. Atmos. Environ. 18: 1507-1515.

Hopke, P.K. (1985). Receptor Modeling in Environmental Chemistry. John Wiley \& Sons, New York.

Hopke, P.K., Xie, Y., Raunemaa, T., Biegalski, S., Landsberger, S., Maenhaut, W., Artaxo, P. and Cohen, D. (1997). Characterization of the Gent Stacked Filter Unit $\mathrm{PM}_{10}$ Sampler. Aerosol Sci. and Technol. 27: 726735.

Karar, K. and Gupta, A.K. (2007). Source Apportionment of PM10 at Residential and Industrial Sites of An Urban Region of Kolkata, India. Atmos. Environ. 84: 30-41.

Kumar, A.V., Patil, R.S. and Nambi, D.S.V. (2001). Source Apportionment of Suspended Particulate Matter at Two Traffic Junctions in Mumbai, India. Atmos. Environ. 35: 4245-4251.

Marcazzan, G.M., Ceriani, M., Valli, G. and Veechi, R. (2003). Source Apportionment of $\mathrm{PM}_{10}$ and $\mathrm{PM}_{2.5}$ in Milan (Italy) Using Receptor Model. Sci. Total Environ. 317: 137-147.

Miranda, R. and Tomaz, E. (2008). Characterization of Urban Aerosol in Campinas, Sao Paulo, Brazil. Atmos. Res. 87: 147-157.

Murray, F., McGranahan, G. and Kuylenstierna, J.C.I. (2001). Assessing Health Effects of Air Pollution in Developing Countries. Water, Air and Soil Pollut. 130: 1799-1804. 
Negi, B.S., Sadasivan, S. and Mishra, U.C. (1988). Factor Analysis in the Interpretation of Aerosol Composition Data. Indian J. Environ. Health. 31: 32-42.

Negi, B.S., Jha, S.K., Chavan, S.B. and Sadasivan, S. (2002). Atmospheric Dust Load and Elemental Composition of Remote Site in India. Environ. Monit. Assess. 73: 126.

Okamoto, S., Hayashi, M., Nakajima, M., Kainuma, Y. and Shiozawa, K. (1990). A Factor Analysis -Multiple Regression Model for Source Apportionment of Suspended Particulate Matter, Atmos. Environ. 24: 2089-2097.

Pope, C.A., Burnett, R.T., Thun, M.J., Calle, E.E., Krewski, D., Ito, K. and Thurston, G.D. (2002). Lung Cancer, Cardiopulmonary Mortality, and Long Term Exposure to Fine Particulate Air Pollution. JAMA. 287: 1132 -1141.

Pope, C.A., Bates, D. and Raizenne, H. (1995). Health Effects of Particulate Air Pollution: Time for Reassessment? Environ. Health Perspec. 103: 472-480.

Sadasivan, S., Negi, B.S. and Mishra, U.C. (1984). Composition and Sources of Aerosols at Trombay, Bombay. Sci. Total Environ. 40: 279-286.

Sadasivan, S. and Negi, B.S. (1990). Elemental Characterization of Atmospheric Aerosols. Sci. Total Environ. 96: 269-279.

Salvador, P., Artinano, B., Diana, G.A., Xavier, Q. and Andres, A. (2003). Identification and Characterization of Sources of $\mathrm{PM}_{10}$ in Madrid (Spain) by
Statistical Methods. Atmos. Environ. 38: 435-447.

Singh, A.K. and Singh, M. (2006). Lead Decline in the Indian Environment Resulting From the Petrol-Lead Phase-out Programme. Sci. Total Environ. 368: 686694.

Song, Y., Xie, S., Zhang, Y., Zeng, L., Lynn, G.S. and Zheng, M. (2006). Source Apportionment of $\mathrm{PM}_{2.5}$ in Beijing Using Principal Component Analysis/Absolute Principal Component Scores and UNMIX. Sci. Total Environ. 372: 278-286.

Srivastava, A., Gupta, S. and Jain, V. K. (2008). Source Apportionment of Total Suspended Particulate Matter in Coarse and Fine size ranges over Delhi. Aerosol Air Qual. Res. 8: 188-200.

Vallius, M., Janssen, N.A.H., Heinrich, J., Hoek, G., Ruuskanen, J., Cyrys, Van Grieken, R., de Hartog, J.J., Kreyling, W.G. and Pekkanen, J. (2005). Sources and Elemental Composition of Ambient $\mathrm{PM}_{2.5}$ in Three European Cities. Sci. Total Environ. 337: 147-162.

Viana, M., Querol, X., Alastuey, A., Gil, J.I. and Menendez, M. (2006). Identification of PM Sources by Principal Component Analysis (PCA) Coupled with Wind Direction Data. Chemosphere. 65: 24112418

Wang, W.C., Chem, K.S., Chem, S.J., Lin, C.C., Tsai, J.H., Lai, C.H., and Wang, S.K. (2008). Characteristics and Receptor Modeling of Atmospheric $\mathrm{PM}_{2.5}$ at Urban and Rural Sites in Pingtung, Taiwan. Aerosol Air Qual. Res. 8: 112-129. 
Xu, X., Barsha, N., and Li, J. (2008). Analyzing Regional Influence of Particulate Matter on the City of Beijing, China. Aerosol Air Qual. Res. 8: 78-93.
Received for review, July 8, 2008 Accepted, August 14, 2008 